\title{
Problem solving skill of students of senior high schools and Islamic high schools in Tegal Regency in solving the problem of PISA based on Polya's stage
}

\author{
Ayu Arfiana *, Ariyadi Wijaya \\ Departement of Mathematics Education, Graduated Program, Universitas Negeri Yogyakarta. \\ Jalan Colombo No. 1, Karangmalang, Yogyakarta, 55281, Indonesia \\ * Corresponding Author. E-mail: ay.timtoni@gmail.com \\ Received: 20 October 2016; Revised: 14 March 2018; Accepted: 31 December 2018
}

\begin{abstract}
This study aimed to describe the students' problem solving skill of senior high school and Islamic high school in Tegal Regency in solving the problem of PISA based on Polya's stage. The type of this study was a survey research with quantitative approach. The population was the students of senior high schools and Islamic high schools in Tegal Regency. A sample of 389 students of grade X from 12 schools was estabilished using the stratified random sampling technique and cluster random sampling. The data were collected by using a test utilizing 12 PISA test items (reliability was 0.668 ). The Description of the data were analyzed using mean score, standard deviation, maximum and minimum score, and the percentage of correct answer. The results showed that the problem solving skill of senior high school and Islamic high school students in Tegal Regency in solving the problem of PISA based on Polya's stage was categorized as low. The indicators of the devising plan and looking back showed that the skill was in a very low category. Viewed from the indicator of carrying out a plan, their skill was in a medium category.
\end{abstract}

Keywords: problem solving skill, problem of PISA, Polya's stage

How to Cite: Arfiana, A., \& Wijaya, A. (2018). Problem solving skill of students of senior high schools and Islamic high schools in Tegal Regency in solving the problem of PISA based on Polya's stage. Jurnal Riset Pendidikan Matematika, 5(2), 211-222. doi:https://doi.org/10.21831/jrpm.v5i2.15783

Permalink/DOI: https://doi.org/10.21831/jrpm.v5i2.15783

\section{INTRODUCTION}

Education plays a very important role in developing and improving human resources capabilities. In the preamble of the Constitution of Republic of Indonesia year 1945 stated that one of the goals of the Republic of Indonesia is to educate the life of the nation and therefore every citizen reserves the right to obtain excellent education in accordance with interests and talents. The progress of a nation can be seen from the development of education. Therefore, Indonesia needs to conduct periodic evaluations to improve the quality of education in order to educate the nation.

The evaluation of education in Indonesia is assessed from the score of national examinations (UN) held every year. There are several subjects that are tested in the examination. One of which is mathematics therefore right from here it can be known the achievement of Indonesian students related to mathematics subjects. Meanwhile, in the international level there is a program that can measure the skill of students in the field of mathematics called as Program International for Student Assessment (PISA). PISA is organized by the Organization for Economic Co-operation and Development (OECD) once every three years. This program aims to evaluate the skill and knowledge of 15year-old students in applying their knowledge (OECD, 2013, p.15).

Indonesia has participated in the PISA test since its inception in 2000; recently Indonesia has participated six times. However, the results obtained are still far from being satisfactory. Based on the assessment of PISA in 2012, the skill of Indonesian students aged 15 years in the field of mathematics, science, and reading is still very low if it is compared to students from other countries. It can be seen from the position of Indonesia who ranked 64 from 65 countries 


\section{Jurnal Riset Pendidikan Matematika, 5 (2), 2018 - 212}

Ayu Arfiana, Ariyadi Wijaya

participating in the PISA test (OECD, 2014). Meanwhile, in 2015 Indonesia was ranked 69 from 76 countries (OECD, 2016). Despite an increase from PISA 2012 results to PISA 2015 but the results obtained are still quite low when compared to the average score of PISA results. Based on data from the Ministry of Education and Culture (Kemendikbud), the average score of students' skill in mathematics increased from 375 in 2012 to 386 in 2015. Significant improvements occur in students' skill in the field of science, from an average score of 382 in 2012 increasing to 403 in 2015 . However, the skill of reading did not experience significant improvement, from an average score of 396 in 2012 to 397 in 2015 (Kemendikbud, 2016).

Factors affecting the low yield of PISA in Indonesia are Indonesian students are poorly trained and unfamiliar in solving PISA characteristic problems (Wardhani \& Rumiati, 2011, pp.1-2). In addition, Alexander (2013) in BCC News Megazine says that language and cultural differences can influence the difficulty level of PISA. A similar statement was delivered by Stephen (2013) that the quality in language translation and cultural differences could be in the assessment of the PISA test. Thus, students feel difficulty in understanding PISA problem. These difficulties make the students do various types of errors in completing the PISA model so that causes the low achievement of PISA in Indonesia. Meanwhile, Wijaya, Van de HeuvelPanhuizen, Doorman, and Robitzsch (2014) argued that the most common mistakes Indonesian students make in solving the PISA problem are misconceptions in understanding and making mathematical modeling. In mathematics, the problems are usually in the form of math problems, but not all math problems can be called problems. According to Hudojo (1988, p.174), something called a problem depends on the knowledge possessed by the student. If the problem faced by the students is a type of problem that is often encountered by them, they solve it using steps that are often used by them. Therefore the problems become very easy for them. Evans (2012) argues that the key aspect of solving a problem is that the problem must be unfamiliar to the person who solves it. According to Polya (1973, p.171) the problem is said to be routine if a problem can be solved by substituting certain data into the problem to be solved, or by following step by step from kinds of similar problems that have been resolved. Meanwhile, Elia, Heuvel-Panhuizen, and Kolovou (2009) mention the non-routine problem arises when a person faces a particular situation, intends to reach the required situation, but does not know how to achieve that goal. Pimta, Tayraukham, and Nuangchalerm (2009) say that mathematical problem is a tool used not only to help students develop their thinking skills but also to help them develop their basic skills in solving problems, especially issues related to daily life.

In the implementation of mathematics learning, problem solving is a very important part (Karatas \& Baki, 2013, p.250). The National Council of Teachers of Mathematics (NCTM) states that problem solving is the focus of mathematical learning, since problem solving is considered as a tool for children in developing mathematical ideas (Van de Walle, 2008, pp.3-4). Meanwhile, one of the objectives of learning mathematics in Indonesia according to the Regulation of the Minister of Education and Culture Number 22 of 2006 on content standards is mentioned that students are encouraged to have the skill to understand the concepts of mathematics, explain interconnected concept and apply concepts or logarithms, flexibly, accurately, efficiently, and appropriate, in problem solving. Kruse (2009, p.16) defines problem solving is the process of taking the correct action in order to meet the objectives. Carreira, Jones, Amado, Jacinto, and Nobre (2016, p.236) explains that problem solving is a type of activity that requires experimentation, exploration, investigation, testing, reflection and discussion, something that is not always considered fully in the school curriculum. Nitko and Brookhart (2011, p.222) mentions that problem solving refers to a type of thinking required when achieving an objective indirectly and students must use one or more higher thinking level to achieve that goal.

One method of problem solving as an alternative to facilitate students in learning is the problem solving invented by Polya. The problem solving stages are hereinafter called Polya's stages. The steps of solving the problem of Polya's stages consist of four steps, namely: (1) understanding the problem; (2) devising a plan; (3) carrying out the plan; and (4) looking back the (Polya, 1973, pp.5-6). By adopting those Polya stages, then in can be assessed the level of students' problem solving abilities by utilizing PISA question models.

Although the skill of students in the PISA test nationally has been discover, but the mapping of students' skill in each region in Indonesia has not been described yet. As a result the survey 
research conducted in Tegal Regency can expand the generalization of the PISA test results and detailed the students' skill in Tegal Regency as well as complement the studies that have been conducted in other regions. Thus, this study aims to describe the students' problem solving skill of senior high school and Islamic high school in Tegal Regency in solving the problem of PISA based on Polya's stage. This survey research in each region in Indonesia can provide information related to map students' problem solving abilities on the PISA model completion. In addition, the description of the problem solving skill of the students can be indirectly made as an evaluation of the learning curriculum, so that it can be a proper reference in making education policy in Indonesia.

\section{METHOD}

This type of research is a survey research. Survey research is one type of research where researchers collect information related to the abilities, opinions, behaviors, beliefs, and knowledge of a population (Fraenkel, Wallen, \& Hyun, 2012, p.393). The activity surveyed in this research is the problem solving skill of senior and Islamic high school students in Tegal Regency, Central Java Province, Indonesia, in completing the PISA model questions based on Polya's stages. These problem solving skill include the skill to understand the problems, plan the problem solving, execute the plans, and interpret the solutions. The skill is obtained from the analysis process based on the results of student test scores in solving the PISA question model which is designed based on Polya's stage. The scores that have been obtained are then categorized into five levels using the standard deviation adapted from Ebel and Frisbie (1991, p.280) ie, very high, high, medium, low and very low.

\section{Research Time and Place}

The research site was conducted in 12 schools in Tegal Regency which conducted by random sampling based on cluster of 15 subdistrict in Tegal Regency which have senior high school or Islamic high school. In the meantime, data collection was conducted on March 9 to April 8, 2017. The survey research was conducted only on grade $\mathrm{X}$ students at 12 schools in Tegal Regency.

\section{Population and Sample}

Combination of stratified random sampling and cluster random sampling were used to collect sample. Stratified random sampling technique is a sampling method through considering certain strata in the population and then samples were taken randomly for each stratum. This technique is conducted in order to include all strata of the population, so that it can explain some strata more detail. In this case there are 3 strata of school levels namely high, medium, and low. Furthermore, in cluster random sampling, sampling is taken based on the established populations clusters (Cohen, Manion, \& Morrison, 2007, pp.111-112).

Determination of sample size is obtained from the population using the following minimum sample formula:

$n=\frac{N}{N d^{2}+1}$ (Riduwan, 2012, p.65) with $n$ is sample size, $N$ is population, $d^{2}$ is error rate

Based on data of National Examination of Tegal Regency shows the number of senior high school and Islamic high school students in IPS program in the academic year 2015/2016 as many as 2.263 students. In the meantime, the desired error rate is $5 \%$. From the calculation of the minimum sample using the formula above is obtained $n=339.78$, so rounded up to 340 . Based on the results of these calculations, it can be said that the minimum sample required is 340 students. In this case, the researcher assumes that the number of students in both public and private high schools and Islamic high schools in Tegal Regency is 28 students, so that from the minimum sample divided by the number of students each class is obtained about 12 schools. Thus, taken 1 class or as many as 28 students from 12 schools, and then it finally sets as a sample in this study.

After categorizing senior and Islamic high school in Tegal Regency into high, medium, and low level, furthermore with stratified random sampling technique then it is taken 12 schools randomly, with high, medium, and low strata respectively 4 schools. After selecting 4 schools in each stratum, then the sampling was determined by cluster random sampling technique, which was taken randomly one $\mathrm{X}$ grade of Senior and Islamic high school at each school which had been selected at the beginning of sampling with stratified random sampling. The study was carried out with 389 students.

\section{Data Collection Techniques and Instruments}

In collecting the data this study applied tests. PISA test model tested is as many as 12 
questions. This type of essay question is used to assess the problem solving skill of Senior and Islamic high school students in solving the PISA model problem based on Polya's stage. Each item is only used to measure one indicator of Polya's stage. From 12 questions of the PISA models each contain three questions for each stage Polya, namely (1) understanding the problem; (2) devising a plan; (3) carrying out the plan; and (4) looking back. Each item is designed based on the content, context, and process domains. Content domains include change and relationship, space and shape, quantity, and uncertainty and data. While the context domain consists of personal context (personal), occupational context (work), societal context (general), and the scientific context (science). The working time of the PISA model is 80 minutes, so that the average time spent each question can be 6.67 minutes.

\section{Data Analysis Technique}

The data obtained in this study is the score of problem solving skill of Senior and Islamic high school in solving PISA question model based on Polya's stages. Student's scores are then classified into five categories referenced from Ebel and Frisbie (1991, p.280) in Table 1.

Table 1. Category of Student Problem Solving Skill

\begin{tabular}{cc}
\hline Score Interval & Category \\
\hline $\mathrm{M}_{\mathrm{i}}+1,5 \mathrm{Sd}_{\mathrm{i}}<\mathrm{X} \leq \mathrm{M}_{\mathrm{i}}+3 \mathrm{Sd}_{\mathrm{i}}$ & Very High \\
$\mathrm{M}_{\mathrm{i}}+0,5 \mathrm{Sd}_{\mathrm{i}}<\mathrm{X} \leq \mathrm{M}_{\mathrm{i}}+1,5 S d_{\mathrm{i}}$ & High \\
$\mathrm{M}_{\mathrm{i}}-0,5 \mathrm{Sd}_{\mathrm{i}}<\mathrm{X} \leq \mathrm{M}_{\mathrm{i}}+0,5 S \mathrm{~d}_{\mathrm{i}}$ & Medium \\
$\mathrm{M}_{\mathrm{i}}-1,5 \operatorname{Sd}_{\mathrm{i}}<\mathrm{X} \leq \mathrm{M}_{\mathrm{i}}-0,5 S \mathrm{~d}_{\mathrm{i}}$ & Low \\
$\mathrm{M}_{\mathrm{i}}-3 \mathrm{Sd}_{\mathrm{i}}<\mathrm{X} \leq \mathrm{M}_{\mathrm{i}}-1,5 \mathrm{Sd}_{\mathrm{i}}$ & Very Low \\
\hline
\end{tabular}

$\mathrm{M}_{\mathrm{i}}$ is mean score ideal $=\frac{1}{2}$ (maximum score ideal - minimum score ideal). $\mathrm{Sd}_{\mathrm{i}}$ is standard deviation ideal $=\frac{1}{6}($ maximum score ideal - minimum score ideal) and $\mathrm{X}$ is empirical score

\section{RESULT AND DISCUSSION}

\section{Students' Problem Solving Skill in General}

In giving PISA question model based on Polya's stages to discover the problem solving skill of students, the answers obtained by students vary, there are fully correct answers, partially correct answers, wrong answers, and there are no answers or empty. The correct answer is the answer that gets full score (full credit), while the answer is half correct that is almost right answer that gets half score (partial credit). The wrong answer is an answer that gets zero score but there is student response, as a result the mistakes can be analyzed. Meanwhile, the empty answer also did not get a score, but there was absolutely no response from the students. The following is the percentage of students' general response in completing PISA question model based on the Polya's stage.

Figure 1 shows that more than a quarter of the students do not answer the questions at all. Meanwhile, the percentage of students who answered correctly was relatively the same as the percentage of students who answered incorrectly, although there were still a few more students who answered incorrectly. Whereas, the percentage of students whose answer was partially correct is lowest among the other types of answers.

Based on the researchers' observations who act as givers, supervisors, and observers, it is known that most students do not understand the purpose of what is asked by the question. It becomes one of the causes of empty student answers, because students have difficulty in understanding the question. As a result they will miss the question and do not answer it. The question of PISA model given to the students using materials that have been studied in junior high school, but somehow the students often forget the concept of the material. In addition, students say the time given is not sufficient to answer all of the given questions. Whereas the allocation of time given is 2 hours lesson ( 80 minutes). Meanwhile, there are 12 PISA question models given, so each question gets the working time for 6 minutes 40 seconds. The given time allocation is actually much longer than the ideal time on the PISA test that is 2.5 minutes per question.

The scores of students problem-solving skill was calculated from the total score of the test. The ideal score of 12 items on the PISA model is 25 and the minimum score is 0 . The categories used can be seen in Table 2. The description of test result about PISA model tested on grade X students in Tegal Regency can be seen in Table 3. 
Jurnal Riset Pendidikan Matematika, 5 (2), 2018 - 215

Ayu Arfiana, Ariyadi Wijaya

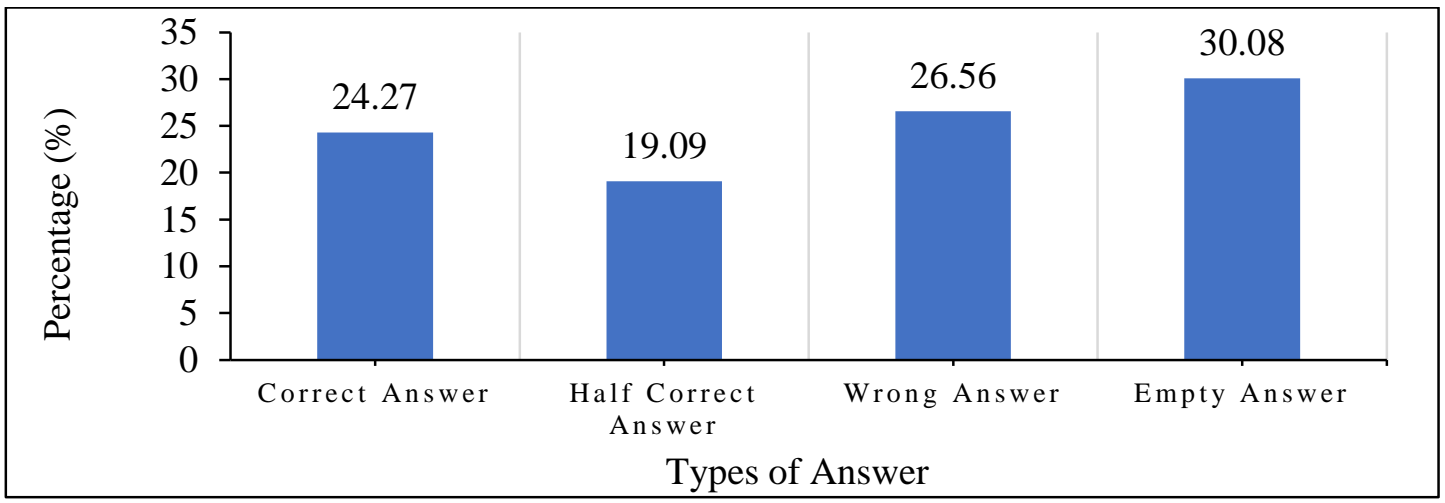

Figure 1. Percentage of Student's Answer Type in Solving the Problem of PISA Based on Polya's Stage

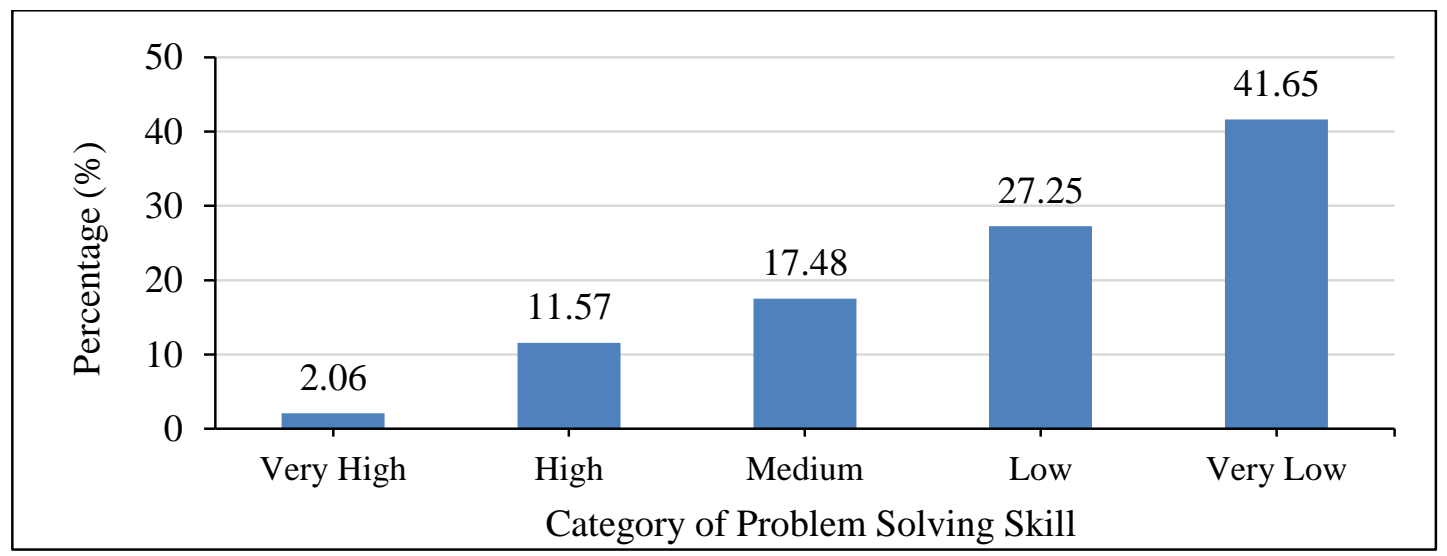

Figure 2. Distribution of Students' Problem Solving Skill

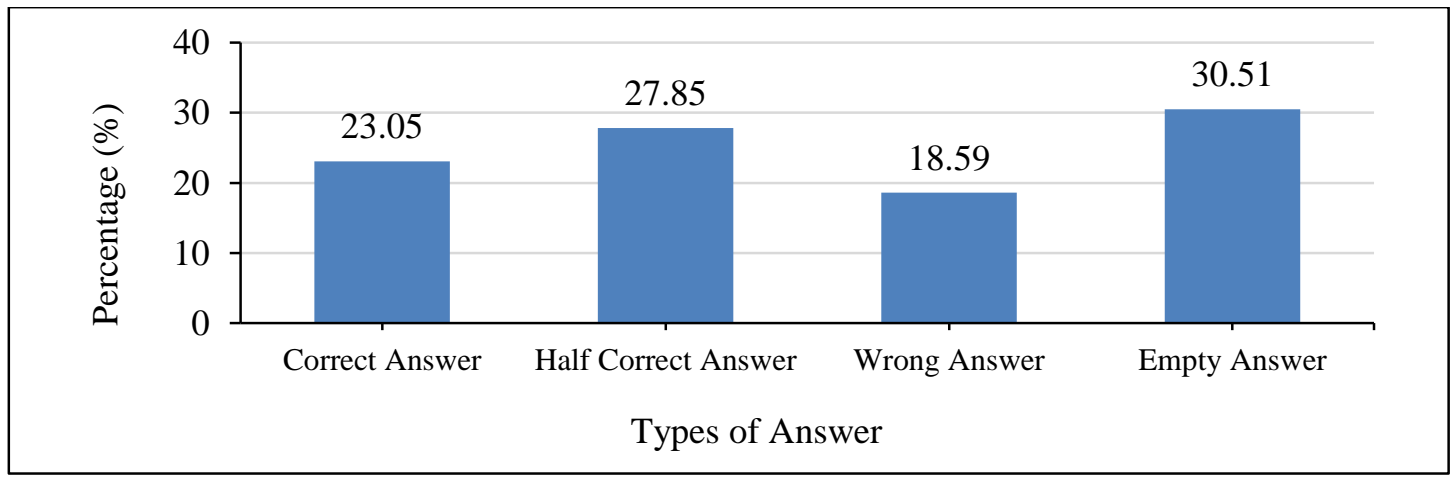

Figure 3. Percentage of Students' Answer Type in Completing PISA Model on Problem Understanding Indicator

Based on Table 3, the mean score obtained by students is in the low category. Therefore it is far from the ideal score. There are many students get the equivalent of the lowest ideal score, but none of the students gets the equivalent of the ideal high score. The distribution of student problem solving skills in completing the PISA model based on the Polya's stage can be seen in Figure 2.

Figure 2 shows that the percentage of problem solving skills of senior and Islamic high school students in Tegal regency is mostly in very low categories and a quarter more students is in the low category. Meanwhile, in very high category the percentage of problem solving skill of students is very low.

Table 2. Category of Problem Solving Skill in General

\begin{tabular}{cc}
\hline Score Interval & Category \\
\hline $18,75<\mathrm{X} \leq 25$ & Very High \\
$14,58<\mathrm{X} \leq 18,75$ & High \\
$10,42<\mathrm{X} \leq 14,58$ & Medium \\
$6,25<\mathrm{X} \leq 10,42$ & Low \\
$0<\mathrm{X} \leq 6,25$ & Very Low \\
\hline
\end{tabular}


Table 3. Description of Students' Problem Solving Skill in General

\begin{tabular}{lc}
\hline \multicolumn{1}{c}{ Description } & Score \\
\hline Mean & 8,22 \\
Standard deviation & 4,76 \\
Maximum score ideal & 25 \\
Maximum score & 21 \\
Minimum score ideal & 0 \\
Minimum score & 0 \\
\hline
\end{tabular}

Students' Problem Solving Skill on Problem Understanding Indicator

The percentage of students' answers when examined from the indicator to understand the question can be seen in Figure 3.

In the indicators of understanding the problem, the percentage of students who answered correctly is fewer than the percentage of students who did not answer the question. In this study there are 3 questions that are used to measure students' skill in understanding the problem. The category of problem-solving skill for this indicator is shown in Table 4.

Table 4. Category of Problem Solving Skill on Problem Understanding Indicator

\begin{tabular}{cc}
\hline Score Interval & Category \\
\hline $5,25<X \leq 7$ & Very High \\
$4,08<X \leq 5,25$ & High \\
$2,92<X \leq 4,08$ & Medium \\
$1,75<X \leq 2,92$ & Low \\
$0<X \leq 1,75$ & Very Low \\
\hline
\end{tabular}

The description of test result of PISA question model tested on grade $\mathrm{X}$ students in Tegal regency Based on problem understanding indicator can be seen in Table 5 .

The mean score of students in Table 5 indicates that the students' skill in problem understanding indicator is in the low category. Although the mean score obtained is far from the highest score ideal. However there are some students who can obtain the equivalent of the maximum score ideal. Furthermore, the distribution of problem solving skills of students on understand the problem indicator can be seen in Figure 4.

Table 5. Description of Problem Solving Skill on Problem Understanding Indicator

\begin{tabular}{lc}
\hline \multicolumn{1}{c}{ Description } & Score \\
\hline Mean & 2,3 \\
Standard deviation & 1,5 \\
Maximum score ideal & 7 \\
Maximum score & 7 \\
Minimum score ideal & 0 \\
Minimum score & 0 \\
\hline
\end{tabular}

Figure 4 shows that the skill of students at the stage of understanding the problem is mostly in the low category, but not the least is also in the category very low and medium. At the stage of understanding the problem, students get difficulties in selecting relevant data, as Wijaya et al. (2014) concludes that the separation of relevant data is the most difficult parts for students, while it is an important parts in the process of understanding a context-based problem (Wijaya et al, 2014). Therefore the factor triggered the number of students answered incorrectly at this stage is because the students are fooled by the information available in the questions. Therefore it makes students feel difficulty in solving the problems (Tias \& Wutsqa, 2015).

\section{The Students' Problem Solving Skill on Devising Plan Indicator}

In devising plan indicator, the percentage of students' answers on the correct answer and the empty answers are presented in Figure 5.

There are 3 items of PISA question model used in measuring students' skill at the planning stage. Figure 5 shows that the percentage of empty answers is the highest and the right answer is the least. To determine the category of students' skill in devising plan indicator, it can be seen in Table 6.

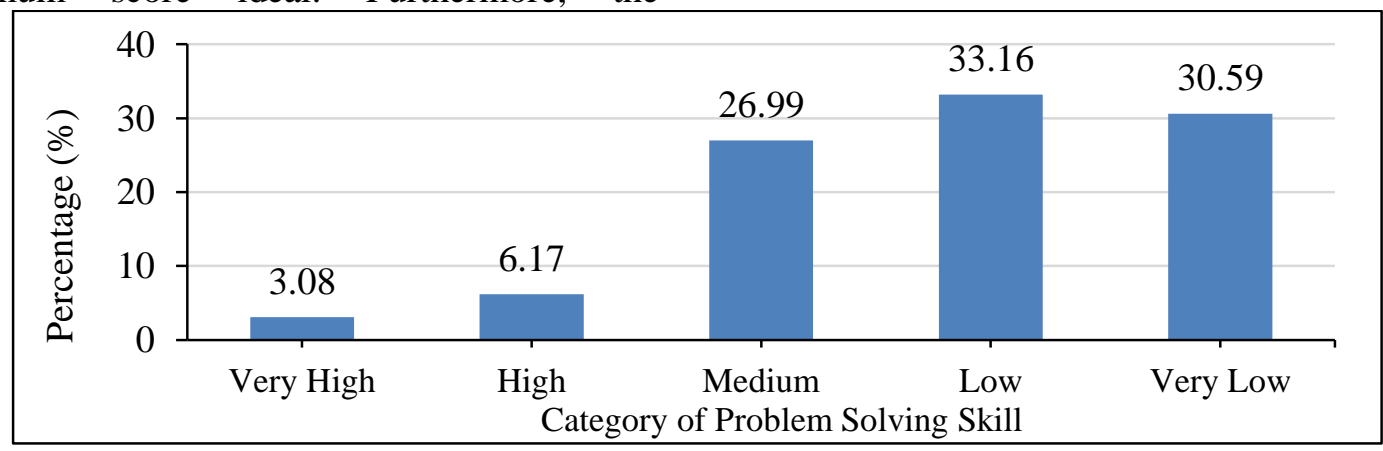

Figure 4. Distribution of Students' Problem Solving Skill on Problem Understanding Indicator 
Jurnal Riset Pendidikan Matematika, 5 (2), 2018 - 217

Ayu Arfiana, Ariyadi Wijaya

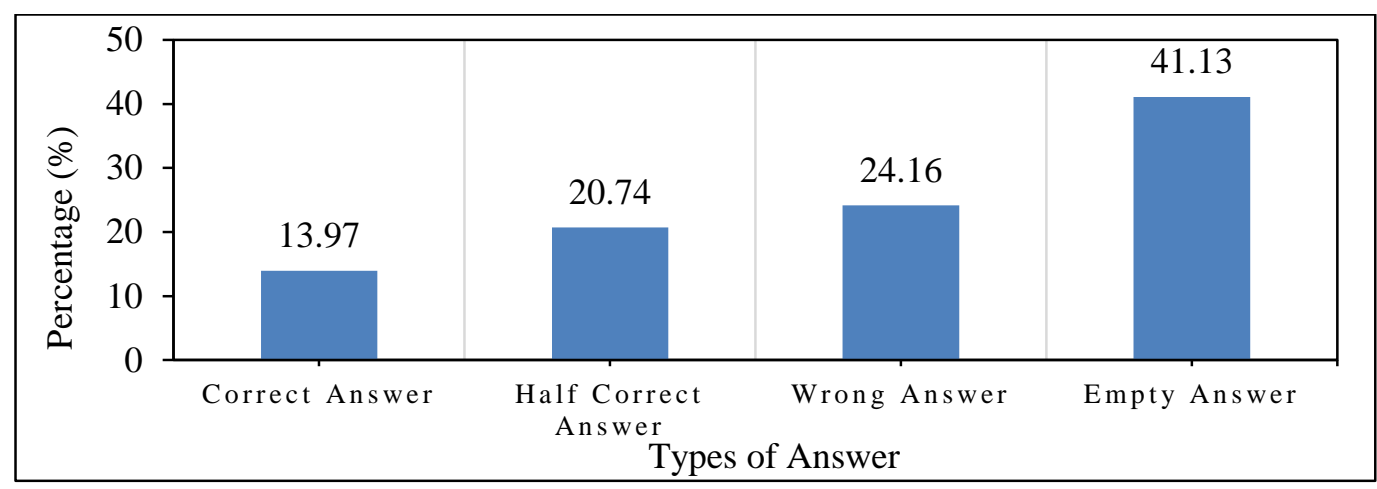

Figure 5. Percentage of Students' Answer Type in Completing PISA Question Model on Devising Plan Indicator

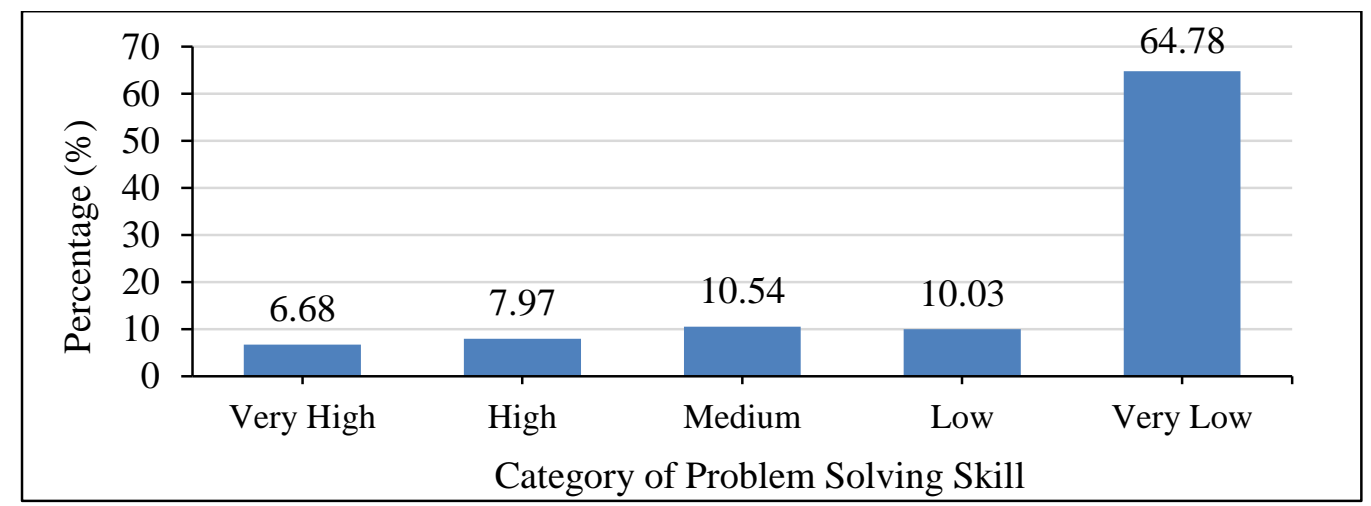

Figure 6. Distribution of Students' Problem Solving Skill on Devising Plan Indicator

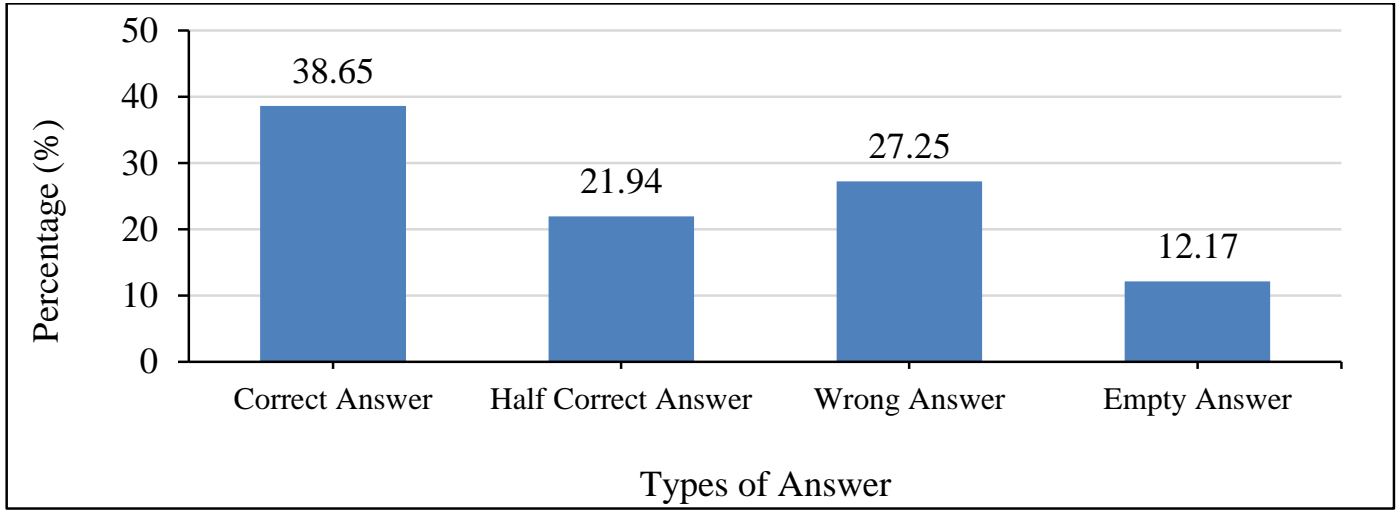

Figure 7. Percentage of Students' Answer Type in Completing PISA Question Model on Carrying Out Plan Indicator

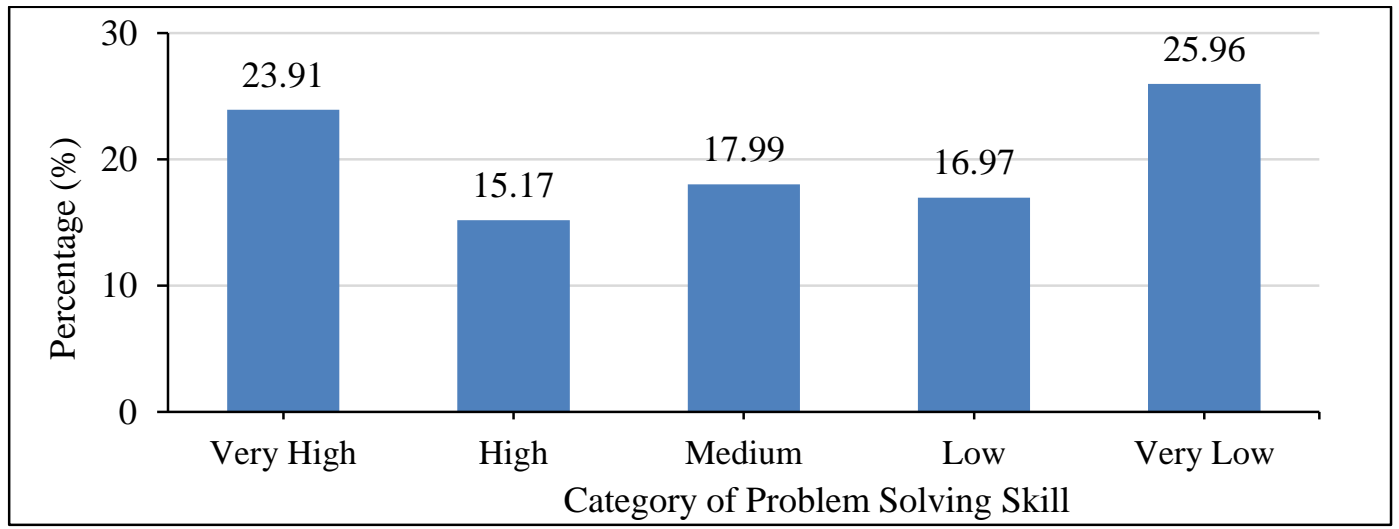

Figure 8. Student Problem Solving Distribution on the Indicators of Carrying out plan 
Jurnal Riset Pendidikan Matematika, 5 (2), 2018 - 218

Ayu Arfiana, Ariyadi Wijaya

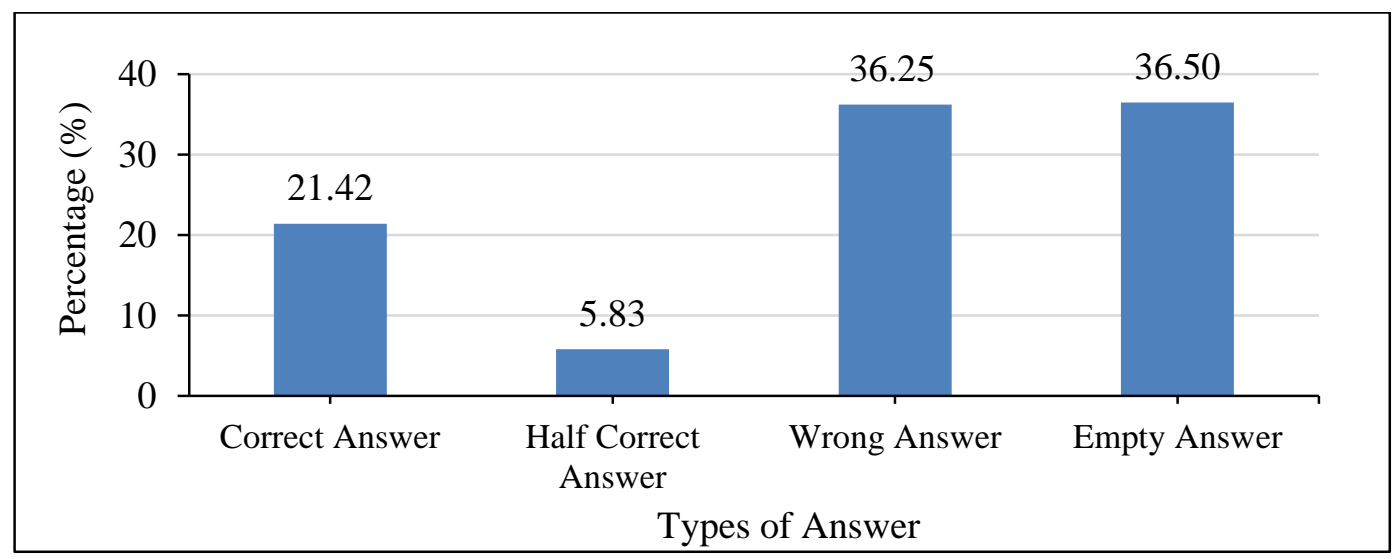

Figure 9. Percentage of Students' Answer Type in Completing PISA Question Model on Looking Back Answers Indicator

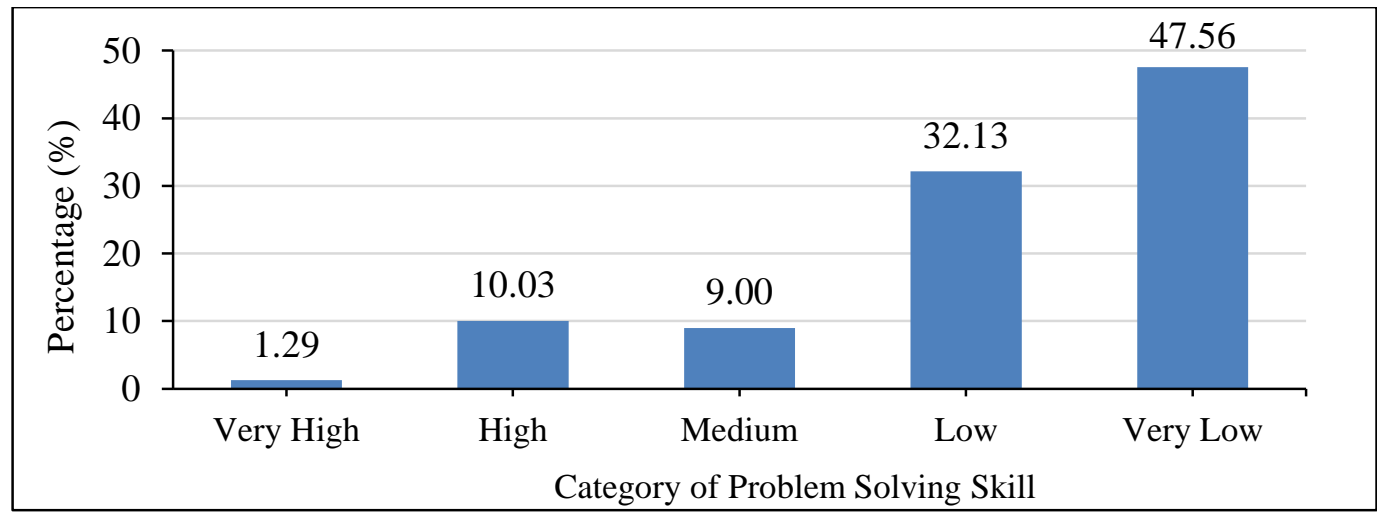

Figure 10. Distribution of Students' Problem Solving Skill o Looking Back Answers Indicator

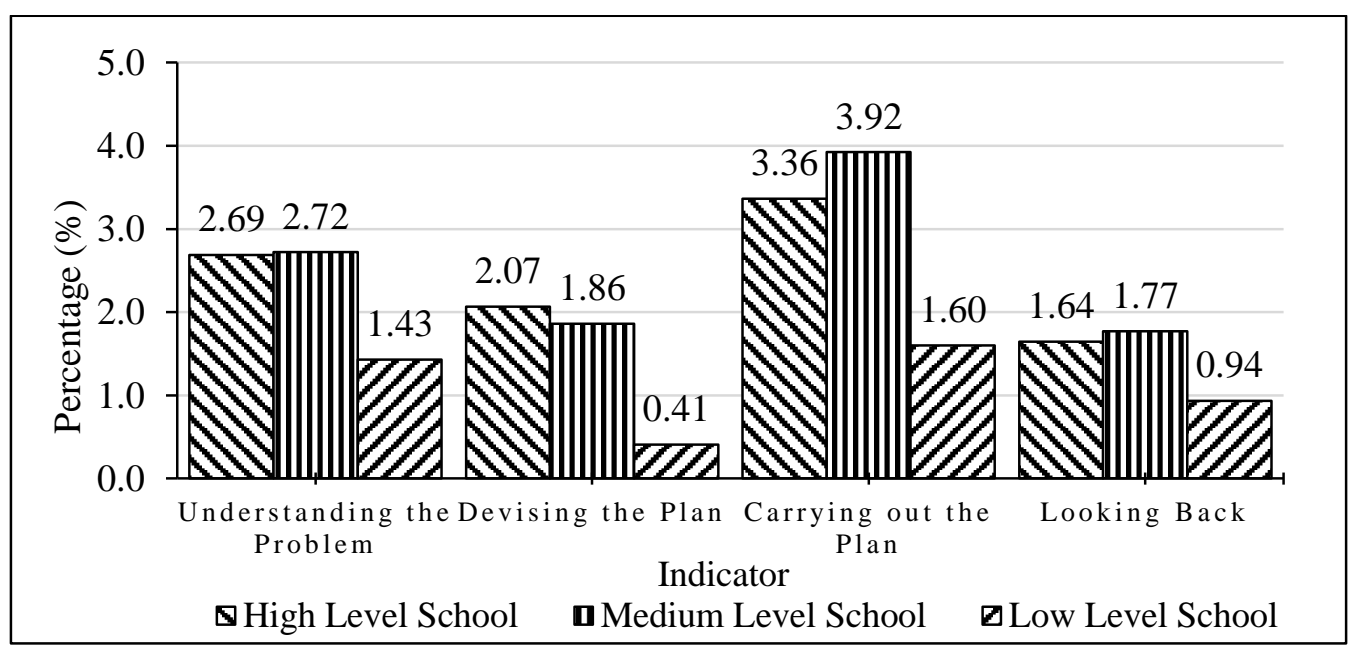

Figure 11. The Average Score of Student Problem Solving Based on Each School Level viewed from the Problem Solving Skills Indicator

Description of test result of PISA question model tested on grade $\mathrm{X}$ students in Tegal Regency for devising plan indicator can be seen in Table 7. The mean score the devising plan is in very low category. The distribution of students' problem solving skills on devising plan indicator can be seen in Figure 6.
Table 6. Category of Problem Solving Skill on Devising Plan Indicator

\begin{tabular}{cc}
\hline Score Interval & Category \\
\hline $4,50<X \leq 6$ & Very High \\
$3,50<X \leq 4,50$ & High \\
$2,50<X \leq 3,50$ & Medium \\
$1,50<X \leq 2,50$ & Low \\
$0<X \leq 1,50$ & Very low \\
\hline
\end{tabular}


Table 7. Description of Students' Problem Solving Skill on Devising Plan Indicator

\begin{tabular}{lc}
\hline \multicolumn{1}{c}{ Description } & Score \\
\hline Mean & 1,47 \\
Standard deviation & 1,64 \\
Maximum score ideal & 6 \\
Maximum score & 6 \\
Minimum score ideal & 0 \\
Minimum score & 0 \\
\hline
\end{tabular}

There are more than half of the students in the category of very low in terms of problem solving skill of students in the stages of devising plan. The result indicates that students have not been able to determine the concept or the appropriate mathematical procedures and the students are too skewed on the context of the real world (Sari \& Wijaya, 2017), therein the error that students do on the question occur.

\section{Students' Problem Solving Skill on Carrying Out Plan Indicator}

The questions at the stage of carrying out plan are considered easier by the students because the percentage of students who answered correctly reaches a quarter more of the number of the students and the percentage of students who do not answer possesses the lowest in comparison to the other stages as shown in Figure 7.

The percentage of students who answered correctly is quite large compared to the indicators discussed earlier. The category of problem solving skill on carrying out plan indicator is presented in Table 8.

Table 8. Category of Problem Solving Skill on Carrying Out Plan Indicator

\begin{tabular}{cc}
\hline Score Interval & Category \\
\hline $4,50<X \leq 6$ & Very High \\
$3,50<X \leq 4,50$ & High \\
$2,50<X \leq 3,50$ & Medium \\
$1,50<X \leq 2,50$ & Low \\
$0<X \leq 1,50$ & Very low \\
\hline
\end{tabular}

The description of test result of PISA question model tested on grade $\mathrm{X}$ students in Tegal Regency for carrying out plan indicator can be seen in Table 9 .

Table 9. Description of Student Problem Solving Skill on Carrying out plan Indicator

\begin{tabular}{lc}
\hline \multicolumn{1}{c}{ Description } & Score \\
\hline Mean & 2,99 \\
Standard deviation & 1,88 \\
Maximum score ideal & 6 \\
Maximum score & 6 \\
Minimum score ideal & 0 \\
Minimum score & 0 \\
\hline
\end{tabular}

The mean score on the indicator of carrying out the plan is higher than the previous indicators that have been presented. In this indicator, students' skill is in the medium category. Furthermore, the distribution of students' problem solving skill on the indicator of carrying out plan can be seen in Figure 8.

Figure 8 shows that students' problemsolving skill at the stage of carrying out plan are moderate. There is more than a quarter of students are in very low category and relatively equal to the number of students who are in very high category. There are still many students who answered incorrectly at this stage. Even there are students who do not give any answer at all. The error which is done by the students is in the process of calculating. According to Sari and Wijaya (2017), this shows that students have difficulties in applying mathematical facts, concepts, and procedures to solve problems.

\section{Students' Problem Solving Skill on Looking Back Answers Indicator}

There are three points of questions used to measure the skill of students on indicator of looking back answers. From the three points of the question, students have difficulty in completing them. It is indicated by the high percentage of wrong answers and empty answers. Further information can be seen in Figure 9.

The percentage of students who give empty answer was relatively the same as the percentage of students who answered incorrectly and both were higher than the percentage of students who make correct answers. It shows that students have difficulties in completing PISA question model. The categories used to determine the level of skill of students on the indicator of looking back can be seen in Table 10 .

Table 10. Category of Problem Solving Skill on Looking Back Answers Indicator

\begin{tabular}{cc}
\hline Score Interval & Category \\
\hline $4,50<X \leq 6$ & Very High \\
$3,50<X \leq 4,50$ & High \\
$2,50<X \leq 3,50$ & Medium \\
$1,50<X \leq 2,50$ & Low \\
$0<X \leq 1,50$ & Very Low \\
\hline
\end{tabular}

Description of test result of PISA question model tested on grade $\mathrm{X}$ students in Tegal Regency for indicator of looking back can be seen in Table 11. 
Table 11. Description of Students' Problem Solving Skill on Looking Back Answers Indicator

\begin{tabular}{lc}
\hline \multicolumn{1}{c}{ Description } & Score \\
\hline Mean & 1,46 \\
Standard deviation & 1,44 \\
Maximum score ideal & 6 \\
Maximum score & 6 \\
Minimum score ideal & 0 \\
Minimum score & 0 \\
\hline
\end{tabular}

The mean score gained from the indicator of looking back is very low. It indicates that the students' skill at the looking back stage of the answer is very low. Furthermore, the distribution of student problem solving skills on the indicator of looking back can be seen in Figure 10.

At the stage of looking back answers, there are only very few students who are in very high category and almost half of the students are in very low category. The results indicate that the students have not been able to interpret the answer into the context yet and have not been able to provide a logical argument regarding the given problem (Sari \& Wijaya, 2017). The results are similar to the findings of Sari and Wijaya (2017) in a study conducted on senior and Islamic high school in the Special Region of Yogyakarta. The findings state that the students' skill to interpret the answers is in very low category, so it can be said that students have not been able to interpret a mathematical answer into the real context properly.

\section{Student Problem Solving Skill Based on School Level}

The study was conducted at three different school levels: high level school with 135 students, medium level school with 130 students, and low level school with 124 students. Description of problem solving skill in term of those three school levels are presented in the Table 12.

Table 12. Description of Student Problem Solving Skill Based on School Level

\begin{tabular}{lccc}
\hline \multirow{2}{*}{\multicolumn{1}{c}{ Description }} & \multicolumn{3}{c}{ School Levels } \\
\cline { 2 - 4 } & High & Medium & Low \\
\hline Mean Score & 9,76 & 10,28 & 4,34 \\
Standard deviation & 4,30 & 4,71 & 2,45 \\
Maximum score ideal & 25 & 25 & 25 \\
Maximum score & 21 & 20 & 13 \\
Minimum score ideal & 0 & 0 & 0 \\
Minimum score & 1 & 0 & 0 \\
\hline
\end{tabular}

Table 12 shows that students" problemsolving abilities at each school level differ from one another. At the high level school the mean score is still far from the masimum score ideal. The score at medium school are higher than high level school. This is because the great number of students in high level school who answered incorrectly, and also in understanding the problem and carrying out plan, thus affecting the mean score obtained. Meanwhile, in low level schools the mean score earned is lower than high and medium level school.

The minimum score at high level school are slightly better than medium and low level school because the minimum score is not the same as the minimum score ideal, so in high level school no students answer completely wrong on whole questions. The mean score obtained at high level school shows the students' problem solving skill are in the low category. Problem solving skill at medium level school are in the low category as well. Furthermore, the low level schools are in very low categories. The distribution of problem-solving skills in each category of those three school levels is presented on Table 13.

Table 13. Percentage of Problem Solving Skill Based on the School Level

\begin{tabular}{cccc}
\hline \multirow{3}{*}{ Category } & \multicolumn{3}{c}{ School Level } \\
\cline { 2 - 4 } & $\begin{array}{c}\text { High } \\
(\%)\end{array}$ & Medium $(\%)$ & $\begin{array}{c}\text { Low } \\
(\%)\end{array}$ \\
\hline Very High & 3,7 & 2,3 & 0 \\
High & 11,1 & 23,1 & 0 \\
Medium & 25,2 & 24,6 & 1,6 \\
Low & 38,5 & 23,8 & 18,5 \\
Very Low & 21,5 & 26,2 & 79,8 \\
\hline
\end{tabular}

Table 13 shows that the problem solving skill of students at high level school is mostly in the low category that is possessed by more than one third of the number of the students. In medium level school, students' problem solving skill in high, medium, low, and very low categories relatively has the same percentage. Problem solving skill at lower level schools are mostly in the very low category marked by more than three quarters of the total number of students. In low level school, there are no students is in the high and very high category, and the percentage of medium category is also very low.

Furthermore, mean score of problem solving skills in completing the PISA question model is described here. This discussion is based on each school level and problem-solving indicator. Description of the mean score of problem solving skill of students at each level school 
based on the problem solving indicator is presented in Figure 11.

Based on Figure 11, the mean of student problem solving scores at high level school get the highest score in understanding the problem, planning problem solving, and looking back the answers. While the mean score in carrying out the plan stage of at high level school is not higher than mean score obtained by the medium level school. Meanwhile, the mean score in low level schools is the lowest than those two school levels at all four indicators.

At the stage of understanding the problem, the high level school earns the highest mean score even though it is relatively the same as the mean score possessed by the medium level school. Meanwhile, low level schools get the lowest mean score. Furthermore, at the devising the plan stage, the highest mean score is obtained by high level school, with a slightly different margin with medium level school. While low level schools at this stage also get the lowest mean score among high and medium level schools. Not much different from the devising plan, at the stage of carrying out plan, low level schools earn the lowest mean score among the medium and high level schools. Meanwhile, at the stage of looking back the answer the highest mean score is possessed by high level schools.

Based on the results of mean score obtained by high school, medium, and low level school it can be concluded that both high level school and medium level school students are more master the problem at the stage of carrying out the plan and have problems at the stage of looking back answer. Meanwhile at low level schools, students are more masterful at the stage of carrying out plan, but they have problems at the devising the plan stage. Thus students at high and medium level schools find difficulties in looking back the answers, whereas students at low level schools find difficulties in devising the plan.

\section{CONLUSIONS}

Based on the result of the study, it can be concluded that the problem solving skill of senior and Islamic high school students in Tegal Regency in completing PISA question model based on Polya's stage is in low category. From the four stages of Polya, in general the lowest is the stage of planning and looking back the answers, which are in very low category. Meanwhile the devising the plan stage is in low category and the stage of carrying out the plan is in medium category.

Based on the school level, students' problem solving skill at high and medium schools are relatively similar, but there is a difference in low level schools only. In high and medium level schools, students' problem solving skill are in low category. While in low-level schools, students' problem-solving skill are in very low category. From those three levels of schools, the highest score are possessed by the stage of carrying out the plan. While, the lowest result for high and medium level schools are in the stage of looking back the answers. Whereas in low level schools the lowest results are at the devising the plan stage.

\section{REFERENCE}

Alexander, R. (2013). How accurate is the PISA test? BBC News Megazine. Retrieved from http://www.bbc.com/news/magazine25299445.

Carreira, S., Jones, K., Amado, N., Jacinto, H., \& Nobre, S. (2016). Youngsters solving mathematical problems with technology: The results and implications of the Problem@Web Project. New York, NY: Springer.

Cohen, L., Manion, L., \& Morrison, K. (2007). Research methods in education. New York, NY: Routledge.

Ebel, R. L., \& Frisbie, D. A. (1991). Essentials of educational measurement ( $5^{\text {th }}$ ed.). Englewood Cliffs, NJ: Prentice-Hall.

Elia, I., Heuvel-Panhuizen, M., \& Kolovou, A. (2009). Exploring strategy use and strategy flexibility in non-routine problem solving by primary school high achievers in mathematics. ZDM Mathematics Education, 41, 605-618.

Evans, B. R. (2012). Editor's perspective article: problem solving abilities and perceptions in alternative certification mathematics teachers. Journal of the National Association for Alternative Certification, 7(2), 34-43.

Fraenkel, J. R., Wallen, N. E., \& Hyun, H. H. (2012). How to design and evaluate research in education. New York, NY: McGraw-Hill.

Hudojo, H. (1988). Belajar mengajar matematika. Jakarta: Depdiknas. 
Karatas, I., \& Baki, A. (2013). The effect of learning environments based on problem solving on students' achievements of problem solving. International Electronic Journal of Elementary Education, 5(3), 249-268.

Kemendikbud. (2016). Survei Internasional PISA. Retrieved from https://goo.gl/2DUwZS

Kruse, P. D. (2009). Working smart: Problemsolving strategies for school leaders. Maryland, MD: Rowman Littlefield.

Nitko, A. J., \& Brookhart, S. M. (2011). Educational assesment of students. Boston, MA: Pearson Education.

OECD. (2013). PISA 2012 Assessment and analytical framework: Mathematics, reading, science, problem solving and financial literacy. Paris, France: OECD Publishing.

OECD. (2014). PISA 2012 results: What students know and can do-student performance in mathematics, reading and science (Volume 1, Revised Edition, February 2014). Paris, France: OECD Publishing.

OECD. (2016) PISA 2015 result in Focus. Paris, France: OECD Publishing.

Pimta, S., Tayraukham, S., \& Nuangchalerm, P. (2009). Factors influencing mathematic problem-solving ability of sixth grade students. Journal of Social Sciences, 5(4), 381-385.

Polya, G. (1973). How to solve it: A new aspect of mathematical method ( $2^{\text {nd }}$ ed.). Garden City, NY: Princeton University Press.

Republik Indonesia. (2006). Pembukaan Undang-Undang Dasar Republik Indonesia Tahun 1945.
Riduwan, R. (2012). Belajar mudah penelitian untuk guru, karyawan dan peneliti pemula. Bandung: Alfabeta.

Sari, R. H. N., \& Wijaya, A. (2017). Mathematical literacy of senior high school students in Yogyakarta. Jurnal Riset Pendidikan Matematika, 4(1), 2017, 100-107. doi:10.21831/jrpm.v4i1.10649

Stephen, M. (2013). PISA: Poor academic standards and on even poorer test. Retrieved from http://www.telegraph.co.uk/education/104 88665/PISA-Poor-academic-standardsand-an-even-poorer-test.html.

Tias, A. A. W., \& Wutsqa, D. U. (2015). Analisis kesulitan siswa SMA dalam pemecahan masalah matematika kelas XII IPA di Kota Yogyakarta. Jurnal Riset Pendidikan Matematika, 2(1), 28. Retrieved from https://journal.uny.ac.id/index.php/jrpm/ar ticle/view/7148/6165

Van de Wall, J. A., Karp, K. S., \& Bay-Williams, J. M. (2010). Elementary \& middle school mathematics: Teaching developmentally ( $7^{\text {th }}$ ed.). Boston, MA: Allyn and Bacon.

Wardhani, S., \& Rumiati. (2011). Instrumen penilaian hasil belajar matematika SMP: Belajar dari PISA dan TIMSS. Yogyakarta: Pusat Pengembangan dan Pemberdayaan Pendidik dan Tenaga Kependidikan (PPPPTK) Matematika.

Wijaya, A., Van de Heuvel-Panhuizen, M., Doorman, M., \& Robitzsch, A. (2014). Difficulties in solving context-based PISA mathematics tasks: An analysis of students' errors. The Mathematics Enthusiast, 11(3), pp. 555-584. 